\title{
Strawberry Cultivar Use in North America
}

Stan C. H okanson ${ }^{1}$ and Chad E. Finn ${ }^{2}$

\begin{abstract}
SUMmaRY. Strawberry (Fragaria xananas D uch.) cultivars used by commercial producers in $\mathrm{N}$ orth America often change rapidly due to several factors including modified cultural practices, processing and marketing practices, the desire for new cultivars with larger and higher quality berries, resistant insect and disease pests, loss of traditional chemical control methods, and private sector breeding programs. Within the past decade, the annual plastic-mulched production system has quickly expanded into eastern $\mathbf{N}$ orth America prompting the need for cold-hardy cultivars adapted to that system. The continuing loss of traditional chemical controls for strawberry insects and diseases, including the impending loss of methyl bromide, has prompted the need for increased insect and disease resistance. In addition, consumer demands for a healthier food product with lower chemical residues has heightened this need. Small fruit experts from across $\mathbf{N}$ orth America provided information on the primary strawberry cultivars used in the recent past, the present, and potential cultivars for the future, as well as on current strawberry acreage in their respective states and provinces.
\end{abstract}

$\mathrm{n}$ a 1968 review of strawberry cultivars in the U nited States, Smith and Scott stated "the selection of strawberry varieties for commercial production can change faster than any other kind of fruit" (Smith and Scott, 1969). In 1989, D aubeny commented on the decision to review the current cultivar situation for major fruit crops grown in N orth America with regards to strawberry, "This crop started the series and is the one which has undergone the most changes with respect to cultivars. $M$ oreover, it is anticipated that there will be more changes in the next decade" (D aubeny, 1989). M uch the same can be said at this juncture in time. The cultivar picture has changed and will continue to change for many of the same reasons cited by $D$ aubeny. In particular, the influence of the genotype by environment interaction, a double-edged sword for the strawberry breeder, will continue to provide a home for new strawberry cultivars and strawberry breeders. The other edge of the sword dictates that regionally specific climatic conditions, suites of pathogens, and regional industry demands will severely limit the potential for one cultivar to serve all needs. As stated in previous reviews, the continued loss of chemical controls for insects and diseases and the growing negative disposition towards their use continues to be a driving force in strawberry cultivar development. In particular, the probable future loss of methyl bromide as a soil fumigant intensifies the need for cultivars that are genetically resistant to known and future strawberry pathogens.

The cost of publishing this paper was defrayed in part by the payment of page charges. U nder postal regulations, this paper therefore must be hereby marked advertisement solely to indicate this fact.

${ }^{1}$ U SD A-ARS Fruit Laboratory, 10300 Baltimore Avenue, Beltsville, M D 20705.

2U SD A-ARS H orticultural Crops Research Laboratory, 3420 O rchard Avenue, Corvallis, OR 97330. 
Table 1. Estimated total strawberry hectares and hectares planted in a plastic mulch production system for the Eastern U. S. and C anadian Provinces in 1996-97 and the contributors of the information.

\begin{tabular}{|c|c|c|c|}
\hline $\begin{array}{l}\text { State or } \\
\text { Province }\end{array}$ & $\begin{array}{l}\text { Total } \\
\text { area } \\
\text { (ha) }\end{array}$ & $\begin{array}{l}\text { Area on } \\
\text { plastic } \\
\text { (ha) }\end{array}$ & Contributor \\
\hline Arkansas & 120 & $\approx 81$ & J. Clark (U niv. of Ark.) \\
\hline Alabama & 220 & 200 & D. H imelrick (Auburn U niv.) \\
\hline Connecticut & 170 & 0 & $\begin{array}{l}\text { R. H elrich (N .E. Agr. Stat. Service) } \\
\text { N. Gauthier (U niv. of Conn.) }\end{array}$ \\
\hline D elaware & 56 & $\approx 4$ & $\begin{array}{l}\text { T. Feurer (D elaware Agr. Stats.) } \\
\text { E. Kee (U niv. of D el.) }\end{array}$ \\
\hline Florida & 2,400 & 2,400 & $\begin{array}{l}\text { C. Chandler (U niv. of Fla.) } \\
\text { C. H inton (Fla. Straw. Growers) } \\
\text { M. Brown (BBI Produce, Inc.) }\end{array}$ \\
\hline Georgia & 40 & 40 & G. Krewer (U niv. of Georg.) \\
\hline Illinois & 320 & $\approx 30$ & A. O tterbacher (U . of III.) \\
\hline lowa & 240 & $\approx 1$ & G. N onnecke (I owa State U niv.) \\
\hline Indiana & 200 & 0 & $\begin{array}{l}\text { B. Bordelon (Purdue U niv.) } \\
\text { S. Erwin (Indiana Plant and Berry Co.) }\end{array}$ \\
\hline Kentucky & 192 & $\approx 4$ & D. Archbold (U niv. of Kentucky) \\
\hline Louisiana & 340 & 340 & R. Constantin (L ouisiana St. U niv.) \\
\hline$M$ aine & 140 & $\approx 2$ & D. $H$ andley (U niv. of $M$ aine) \\
\hline M aryland & 200 & $\approx 16$ & $\begin{array}{l}\text { G. Galletta (U SD A-ARS, B eltsville) } \\
\text { C. H omann (M ary. Agr. Stats.) } \\
\text { B. Rouse (U niv. of M ary.) }\end{array}$ \\
\hline M assachusetts & 200 & $\approx 3$ & $\begin{array}{l}\text { R. H elrich (N .E. Agr. Stat. Service) } \\
\text { T. N ourse (N ourse Farms, Inc.) } \\
\text { S. Schloemann (U niv. of M ass.) }\end{array}$ \\
\hline M ichigan & 680 & 0 & $\begin{array}{l}\text { J. } H \text { ancock ( } M \text { ich. State U niv.) } \\
\text { E. } H \text { anson ( } M \text { ich. State U niv.) }\end{array}$ \\
\hline M innesota & 400 & 0 & J. Luby (U niv. of M inn.) \\
\hline M ississippi & 30 & $\approx 16$ & B. Smith (U SD A-ARS, Poplarville) \\
\hline M issouri & 200 & $\approx 8$ & P. Byers (S.W. M issouri St. U niv.) \\
\hline $\mathrm{New} \mathrm{H}$ ampshire & 80 & $\approx 2$ & B. Lord (U niv. of N.H.) \\
\hline New York & 880 & $\approx 12$ & $\begin{array}{l}\text { K. M aloney (Cornell U niv.) } \\
\text { M. Pritts (Cornell U niv.) }\end{array}$ \\
\hline N orth Carolina & 960 & 480 & $\begin{array}{l}\text { J. Ballington (N.C. State U niv.) } \\
\text { B. Poling (N.C. State U niv.) }\end{array}$ \\
\hline New Jersey & 180 & $\approx 24$ & J. Fiola (Rutgers U niv.) \\
\hline Ohio & 520 & $\approx 10$ & $\begin{array}{l}\text { J. Scheerens (O hio State U niv.) } \\
\text { T. Wall (O hio State U niv.) }\end{array}$ \\
\hline Pennsylvania & 520 & $\approx 10$ & B. Goulart (Penn. State U niv.) \\
\hline Rhode I sland & 24 & 0 & $\begin{array}{l}\text { R. H elrich (N .E. Agr. Stat. Service) } \\
\text { K. M enezes (U niv. of R.I.) } \\
\text { L. T ewksbury (U niv. of R.I.) }\end{array}$ \\
\hline South Carolina & 120 & $\approx 108$ & D. Layne (Clemson U niv.) \\
\hline Tennessee & 283 & 67 & A. Rutledge (U niv. of Tenn.) \\
\hline Vermont & 120 & $\approx 4$ & V. Grubinger (U niv. of Vermont) \\
\hline Virginia & 80 & $\approx 50$ & C. O 'D ell (Virg. Polytechnic U niv.) \\
\hline West Virginia & 16 & $\approx 2$ & D. Yoder [U niv. of West Virg. (Ret.)] \\
\hline Wisconsin & 600 & $\approx 3$ & B. Smith (U niv. of Wisc.-River Falls) \\
\hline New Brunswick & 336 & 0 & A. Jamieson (Agr. Canada-N. Scotia) \\
\hline N ewfoundland & 96 & 0 & A. Jamieson (Agr. Canada-N. Scotia) \\
\hline N ova Scotia & 448 & 0 & A. Jamieson (Agr. Canada-N. Scotia) \\
\hline O ntario & 2298 & $\approx 20$ & $\begin{array}{l}\text { A. Dale (U niv. of Guelph) } \\
\text { K. Schooley (Ont. M inistry of Agr.) }\end{array}$ \\
\hline Quebec & 2639 & 0 & $\begin{array}{l}\text { S. Khanizadeh (Agr. Canada-Q uebec) } \\
\text { M. Lareau (Agr. Canada-Q uebec) }\end{array}$ \\
\hline
\end{tabular}


The rapid growth in popularity of theannual hill production system (plasticulture) in the southeastern $U$ nited States and portions of the Atlantic seaboard arealso influencing the cultivar picture in theeastern U nited States. O Ider cultivars such as 'C handler' and 'Allstar' are experiencing a resurgence in popularity in the system in these regions. As the system is employed further north, there is a great need for northern-adapted cultivars that will perform well in the plasticulture system. In addition, anthracnose (C olle totrichum sp.) fruit and crown rots, formerly southeastern problems, are now becoming issues for the whole of the eastern industry as well. Simply stated, the strawberry cultivar picture will continue to change in the future, necessitating the presence of several regional strawberrybreeding programs and a periodic review of the strawberry cultivar situation in N orth America.

In a manner similar to the previous N orth American strawberry surveys, (Bringhurst and Voth, 1979; Caldwell, 1989; $D$ ale, 1989; D aubeny, 1979; G alletta, 1979; L awrence, 1989; Luby, 1989; O urecky, 1979; Smith and Scott, 1969), we have considered the current strawberry cultivar situation on a regional basis. The current treatment deviates slightly in that the eastern North America is broken up into seven regions. Like the previous survey efforts, information was gathered from small fruit experts on a state by state, province by province basis (Table 1). Without their generous cooperation, preparation of this manuscript would not have been possible. We wish to extend all the credit for the contents of this article to our participating colleagues while we will accept all criticism for any shortcomings or mishandling of the information they so generously provided.

\section{Strawberry cultivars in eastern North America}

StrawberRy cultivars for the NORTHEASTERN UNITED STATESCONNECTICUT, MAINE, MASSACHUSETTS, NEW HAMPSHIRE, NEW YORK, RHODE ISLAND, AND VERMONT. In general, the strawberry industry in the $\mathrm{N}$ ortheastern region of the $U$ nited Statesis made up of growers who produce their crop on $<2$ ha ( 5 acres) of land and use the matted-row production system (Table 1). G enerally these o perations areconcentrated around population centers where the growers market the crop via $U$-pick or prepicked on-farm sales. $M$ ost strawberry operations in the region are part of a diverse multicrop farming operation in which the strawberry crop is the lead-in commodity for the season. $\mathrm{H}$ owever, the existence of specialized operations of up to 40 ha (100 acres) dedicated to strawberries should not be overlooked.

The availability of land for rotation in the N ortheast is a significant factor in cultivar selection. Growers who were not land restricted, e.g. Vermont, and who practiced longer crop rotations, often relied more heavily on the red stele root rot, (Phytophthora fragariaeH ickman var. fragariae) susceptible cultivars such as ' $\mathrm{H}$ oneoye' and 'Jewel'. If not cited specifically, cultivar descriptions can be found in TheBrooksand OImoR egi ter of Fruit and $\mathbf{N}$ utsVarieties( 3 rd ed.). In more populated states such as Connecticut, growers are land limited and cannot practice long rotation schedules. In these situations the growers rely more heavily upon red stele resistant cultivars such as 'Allstar' and 'E arliglow', despite their lower yield potentials.

From the mid-1980s to the present, 'Earliglow' and ' $\mathrm{H}$ oneoye' have been the primary early-season cultivars in the N ortheast (Table 2). Although 'Earliglow' acreage has declined dueto itssmall fruit size, it is still widely planted due to its early fruiting season and outstanding flavor characteristics. 'Earliglow' is still the thirdhighest selling cultivar in the $\mathrm{N}$ ortheast (Table 3 ) and is one of the few strawberry cultivars that has name recognition with consumers. 'H oneoye' has been popular in the $\mathrm{N}$ ortheast because it is winter hardy and it reliably produces a large crop of bright red fruit, which areprominently displayed, all important charactersfor theU - pick growers. H owever, 'H oneoye' is susceptible to at least eight of the ten American races of the red-stele pathogen ( $M$ aas et al., 1989). Some growers report that 'H oneoye' gets poor flavor ratings with customers, which has led to some decline in acreage. In addition, it has poor shelf life (dark red skin color) a liability for wholesale marketing. Despite these shortcomings, ' $\mathrm{H}$ oneoye' is still the number two selling strawberry cultivar in the $\mathrm{N}$ ortheast ( $T$ able 3 ).

Currently, 'Annapolis' is planted in the Northeast as an early-season alternative to 'Earliglow' and 'H oneoye'. Although it is smaller in size and does not yield as well as 'H oneoye', 'Annapolis' is red stele resistant with better fruit size and yield than 'E arliglow'. For the early-season, 'N ortheaster' has very good potential producing well in the $\mathrm{U}$-pick and wholesale markets. The early-season fruit are attractiveand the flavor, which gets mixed reviews, has been said to rival that of 'E arliglow' by some proponents. Conversely, the grape-like flavor characteristic, which is inherited from its 'Holiday' parent, may limit the broad-scale appeal of the cultivar.

For the midseason, the primary cultivarsin therecent past were 'Allstar', 'Kent', and 'Redchief'. Presently, the cultivar picture looks much the same with 'Redchief' having been replaced by 'Cavendish'. 'Cavendish' is currently competing with 'Kent' and 'Allstar' asthe predominant midseason cultivar in the region. However, 'Cavendish' has not lived up to early expectations due to ripening problems (white shoulders) that develop in high temperature conditions. Some growersare managing the problem through theuse of evaporative cooling. 'Allstar' continuesto bethemost widely grown midseason cultivar in the region despite light-colored fruit and average flavor. I t continues to be the top yielding cultivar in the midseason despite having been released over 15 yearsago (Galletta et al., 1981). 'M ira', a 1996 midseason release from $\mathrm{N}$ ova Scotia, has attracted attention from the region's growers due to its productivity, large fruit size and good quality. The new releases ' $M$ ira', 'Primetime', 'D elmarvel', and 'Winona' have not been evaluated enough in the region to determine how much potential they have.

'Blomidon' was a promising lateseason cultivar in the mid-1980s and was quickly replacing 'Sparkle' and 'M icmac' as the primary late-season cultivar in the region. U nfortunately, J uneyellowsdeveloped in 'Blomidon', leading to its demise (J amieson and Sanford, 1996), leaving northeastern growers in need of a good late-season cultivar. 'J ewel' is currently the top selling cultivar in thenortheastern U .S. (Table 3) and the number one late season cultivar (Table 2). 'J ewel' has proven to be highly productive with good fruit and flavor characteristics making it useful for the wholesale and 
$\mathrm{U}$-pick trades. The biggest drawback for 'J ewel' is its susceptibility to red stele root rot.

Since the 1980s, the U SDA, under the direction of D r. G ene Galletta, has been involved in a cooperative program with the $U$ niversity of $M$ aine to produce winter-hardy cultivars that were resistant to a new race of red stele root rot that appeared in the state (M aas et al., 1988). Thiscollaboration has produced $\approx 30$ MEUS ( $M$ aine U SDA) selections since 1990 that are at various stages of evaluation. Selections that yield with 'H oneoye' and produce high quality fruit suitable for the $U$-pick market may find a place in the $\mathrm{N}$ ew England region. O ne of the most often cited needs for the future in the region is a high quality late-season cultivar to replace ‘Blomidon'. G row- ers would also like an early-season cultivar with the fruit quality characteristics of 'Earliglow' and the yield potential of ' $\mathrm{H}$ oneoye'. Cultivarswith resistance to red stele root rot, verticillium wilt (Verticillium sp.) and elements of the black root rot complex (Pythium sp., R hizoctonia sp.) and root-lesion nematodes (Pratylenchus spp.) are also prominently mentioned future needs.

StrawberRy cultivars for the MID-ATLANTIC UNITED STATES-DELAWARE, MARYLAND, NEW JERSEY, VIRGINIA, AND WEST VRGINIA. U nlike the northeastern strawberry production region, themidAtlantic region is currently experiencing afairly distinct dichotomy in strawberry production systems. Directly adjacent to the Atlantic seaboard and increasing in a southerly progression, more acreage is being planted in the annual, raised-bed, plastic-mulched (plasticulture) production system (Table 1). This production system has generated excitement among the region's growers due primarily to the earlier crop that can be produced and the higher price that is paid for this early crop. I n addition, growers appreciate the ease of harvest of clean fruit, larger fruit, and higher yields compared to the traditional matted row. Presently, the plasticulture growers have been using cultivars developed in the U niversity of California, Davis, program, (UCD), e.g., 'C handler' and 'C amarosa', or from the $U$ niversity of Floridaprogram, e.g., 'Sweet Charlie'.

Growers in the mid-Atlantic region areinterested in northern-adapted cultivars that will perform well in the

Table 2. Principal strawberry cultivars grown in eastern N orth America in the early, middle, and late seasons in the recent past, ${ }^{z}$ present, ${ }^{y}$ and predictions for the future. ${ }^{x}$

\begin{tabular}{|c|c|c|c|}
\hline Season & Past & Present & F uture \\
\hline \multicolumn{4}{|c|}{ N ortheastern U nited States (M aine, Vermont, N ew H ampshire, M assachusetts, R hode I sland, C onnecticut, and N ew York) } \\
\hline Early & Earliglow, $\mathrm{H}$ oneoye & Annapolis, Earliglow, $\mathrm{H}$ oneoye & N ortheaster \\
\hline Mid & Allstar, Kent, Redchief & Allstar, Cavendish, Kent & Mira \\
\hline Late & Blomidon, Sparkle & Jewel & Winona \\
\hline \multicolumn{4}{|c|}{ M id-Atlantic U nited States (D elaware, M aryland, $N$ ew Jersey, West Virginia, and Virginia) } \\
\hline Early & Earliglow, $\mathrm{H}$ oneoye & Annapolis, E arliglow, $\mathrm{H}$ oneoye & N ortheaster \\
\hline Mid & Allstar, Redchief & Allstar, Cavendish, Jewel & Primetime \\
\hline Late & D elite, J erseybelle, Lateglow & Lateglow & Latestar \\
\hline \multicolumn{4}{|c|}{ Southeastern U nited States (Alabama, Florida, G eorgia, Louisiana, Mississippi, N orth C arolina, and South C arolina) } \\
\hline Early & Earlibelle, Earliglow, Sunrise & Earliglow & Unknown \\
\hline Mid & Atlas, Titan, Cardinal & Allstar, Atlas, Cardinal & Unknown \\
\hline Late & Apollo, D elite, Tennessee Beauty & Apollo, Jewel & Unknown \\
\hline Plastic & $\begin{array}{l}\text { Chandler, Cardinal, D ouglas, E arlibelle, } \\
\text { Selva, Pajaro, O so Grande,T angi }\end{array}$ & $\begin{array}{l}\text { Camerosa, Chandler, Sweet Charlie, } \\
\text { Pajaro, Selva, others }{ }^{w}\end{array}$ & Unknown \\
\hline \multicolumn{4}{|c|}{ M idsouthern U nited States (Arkansas, Kentucky, M issouri, and Tennessee) } \\
\hline Early & Earliglow, Sunrise, Pocahontas & Earliglow & Chambly \\
\hline M id & $\begin{array}{l}\text { Allstar, Cardinal, Guardian, H oneoye, } \\
\text { Redchief, Surecrop }\end{array}$ & $\begin{array}{l}\text { Allstar, Cardinal, H oneoye, } \\
\text { J ewel, Redchief }\end{array}$ & Un \\
\hline Late & ArKing, Lateglow & ArKing, La & Unknown \\
\hline \multicolumn{4}{|c|}{ M idwestern U nited States (I llinois, Indiana, O hio, and Pennsylvania) } \\
\hline Early & Earliglow, $\mathrm{H}$ oneoye & Earliglow, $\mathrm{H}$ oneoye & N ortheaster \\
\hline M id & Allsta & Allstar, Kel & \\
\hline Late & Blomidon, Guardian, Jewel, Scott, Sparkle & J ewel, Lat & None \\
\hline \multicolumn{4}{|c|}{ U pper-midwestern U nited States (Iowa, M ichigan, M innesota, and Wisconsin) } \\
\hline Early & Earliglow, $\mathrm{H}$ oneoye, Veestar & Annapolis, Earliglow, H oneoye, Veestar & Chambly, N ortheaster \\
\hline M id & Allstar, Kent, Redchief, Redcoat & Allstar, Cavendish, Kent, Glooscap & M esabi, M ira \\
\hline Late & Blomidon, Bounty, Sparkle & Bounty, J ewel, Lateglow, Sparkle & Latestar, Winona \\
\hline \multicolumn{4}{|c|}{$\begin{array}{l}\text { Eastern C anada (O ntario, Atlantic Provinces ( } \mathrm{N} \text { ova Scotia, } \mathrm{N} \text { ew Brunswick, Prince E dward I sland, and } \mathrm{N} \text { ewfoundland), and } \\
\text { Q uebec) }\end{array}$} \\
\hline Early & Veestar & Annapolis, Veestar & M ohawk \\
\hline M id & Kent, Redcoat, Glooscap, H oneoye & Cavendish, Kent, H oneoye, Jewel & Mira \\
\hline Late & $\begin{array}{l}\text { Blomidon, Bounty, M icmac, Sparkle, } \\
\text { Vantage }\end{array}$ & $\begin{array}{l}\text { Bounty, Govenor Simcoe, M icmac, } \\
\text { Sparkle }\end{array}$ & Startyme \\
\hline
\end{tabular}

zThe recent past was considered to be from $\approx 1985-90$.

YThe present was considered to be from $\approx 1990-97$.

$x$ T he future was considered to be $\approx 5$ to 10 years into the future.

wo thers were proprietary cultivars and older cultivars such as ' $\mathrm{O}$ so $\mathrm{G}$ rande'. 
plasticulturesystem. N orthern-adapted J une-bearing cultivarssuch as 'L atestar' and ' $\mathrm{N}$ ortheaster' havebeen mentioned as highly promising options for the plasticulture system (O 'D ell, 1998). The other consideration for the region will betheoption of carrying the planting over for one or more years. In California, Florida, and the southeastern U.S., the plastic-mulched systems are most commonly fruited only one year. The high planting densities used in these systems, upwards of 43,000 plants/ ha $(17,400$ plants/ acre), create ideal conditions for the spread of many strawberry diseases, including anthracnose fruit and crown rots ( $\mathrm{Col}$ letotrichum sp.), which were formerly considered southeastern problems. In addition, after a year, the plants generally develop so many crowns that fruit sizeissignificantly compromised. These conditionsmakeit difficult for carryover plantings to be economically viable. Cultivars will need to be developed that do not proliferate an excessive number of crowns when grown in the plasticulture system for more than one year. I nterestingly, one of the big problems cited with the plasticulture system in the region has been voles ( $\mathrm{M} \mathrm{i-}$ crotusspp.), which eat the plants (particularly those under floating row cover), tunnel in and out of the plastic mulch and chew through drip irrigation tubing.

$\mathrm{H}$ istorically, the matted row has been the predominant production system in the region and it continuesto be of significance in areas removed from the seaboard and at higher elevations. 'Earliglow' and 'H oneoye' were the primary early-season cultivars grown in the matted-row system (Table 2) and continue to be the predominant cultivars to this day with some 'Annapolis' acreage occurring, primarily in the northern portions of the midAtlantic. For the near future, ' $N$ ortheaster' appears to be a cultivar with significant promise. 'Northeaster' is performing well over the entire region in both production systems. As mentioned previously, its only apparent limitation seems to be a grape-like flavor, which some individuals find objectionable.

The primary midseason cultivars used in the region were 'Allstar' and 'Redchief' (Table 2), although 'Raritan' and 'L ester' weremoreprominent in $\mathrm{M}$ aryland and $\mathrm{New}$ Jersey. Currently 'Allstar', 'C avendish', and 'Jewel' are the principal midseason cultivars for the region in the mattedrow system. For the future, the verdict is still out regarding the most recently released midseason cultivars; although, 'Primetime' isoften mentioned ashaving considerable potential.

Late-season strawberry production in the mid-Atlantic region is a dubious proposition. M ost of the region begins experiencing high temperatures and humidity by mid-J une, which severely limits the interest of $U$ pick customersas well as the interest of growers to harvest prepicked berries. $\mathrm{H}$ istorically, 'D elite' has been the primary late-season cultivar in the southern part of theregion, with 'J erseybelle' and 'Lateglow' predominating in the northern part of the region (T able 2 ). Currently, 'Lateglow' is the most widely used late-season cultivar with considerable interest being shown in 'L atestar' in the matted-row and plasticulture production systems. Availability of a firm, high-quality late-season or bicropping everbearer type cultivar could stimulate more interest in later season strawberry production.

In the future, the interest in the plasticulture system will continue to grow and northern-adapted cultivars that will perform on the plasticulture system in either an annual or perennial fashion should be developed. Strawberry production in the mid-Atlantic region is subjected to high disease pressures due to the use of plastic mulches, longer growing seasons, higher heat and humidity and, as a result, future cultivars will need to have increased disease resistance, particularly to anthracnosefruit and crown rots caused by Colletotrichum sp.

StrawberRy CULTIVARS FOR THE SOUTHEASTERN UNITED STATES-ALABAMA, FLORIDA, GEORGIA, LOUISIANA, MISSISSIPPI, NORTH CAROLINA, AND SOUTH CAROLINA. The southeastern region is now almost completely dominated by the annual plasticulture production system (Poling, 1994) (T able1). Floridaand L ouisiana were the first in the region to adopt the system. Louisiana began producing strawberries in the $C$ alifornia type system in the mid-1950s and Florida has been using this system since the mid-1960s. Until the mid1980s the Louisiana growers relied almost entirely on 'T angi' (C aldwell, 1989). Anthracnose epidemics in grower-produced 'T angi' nurserystock forced the growers to experiment with the cultivar 'Chandler' in the mid1980s. 'C handler' quickly became, and continues to be, the number one cultivar used in the state despite the fact that it is anthracnose susceptible as well. Currently, Florida is the only state in the region for which ' $\mathrm{C}$ handler' is not the primary plasticulture cultivar.

TheFloridastrawberry industry is directed entirely towards the winter fresh market. Strawberriesare produced in 19 Florida counties; however, $90 \%$ of thecrop isproduced in $\mathrm{H}$ illsborough County. The first fruit are generally

T able 3. T op five selling strawberry cultivars in terms of volume for 1996-97 season for seven eastern $\mathrm{N}$ orth American strawberry nurseries.

\begin{tabular}{|c|c|c|c|c|c|}
\hline N ursery & 1 & 2 & 3 & 4 & 5 \\
\hline B rittingham Plant Farms I nc., Salisbury, M d. & Earliglow & Allstar & H oneoye & Jewel & Cavendish \\
\hline D aisy Farms, D ecatur, M ich. & H oneoye & J ewel & Allstar & Earliglow & Winonay \\
\hline Indiana B erry \& Plant Co., H untingburg, Ind. & H oneoye & Earliglow & Jewel & Allstar & Cavendish $^{x}$ \\
\hline Krohne Plant Farms, D owagiac, M ich. & Jewel & Allstar & Earliglow & H oneoye & Kent \\
\hline
\end{tabular}

zSales primarily to homeowners.

ySales heavily influenced by nursery sales.

×Several cultivars were about equal (fifth) in sales volume including 'C avendish', 'N ortheaster', 'D elmarvel', 'Winona', 'M ohawk' and 'Primetime'. 
harvested in late $O$ ctober, with the primary shipping season beginning in late $\mathrm{N}$ ovember. $\mathrm{H}$ arvests continueuntil early A pril when the price is no longer competitive with that of Californiaproduced fruit. Some Florida growers with good local markets will continue to harvest into A pril or early $M$ ay. The industry has tripled over the last 12 years and thestateranks as the number two producer of fresh market strawberries in the $\mathrm{U}$ nited States.

Floridagrowersused cultivars developed in the U CD program, such as 'Pajaro', 'Selva', and 'O so Grande' (Table 2). 'Pajaro' was planted on $65 \%$ of the Florida acreage until the crop was devastated by anthracnose fruit rot caused by $C$ olletotrichum acutatum J.H. Simmonds in the 1986-87 season. By 1989, 'Selva' was the leading cultivar in the state due in large part to its early fruit production. 'Selva's' extreme susceptibility to two-spotted spider mite (TetranychusurticaeK och) led to its downfall. 'O so Grande' reached its peak in Florida in 1993-94 when it occupied $55 \%$ of the Florida strawberry acreage. Currently, 'Sweet Charlie', released from the U niversity of Florida breeding program (Chandler et al., 1997), is the number one cultivar in the state, occupying $37 \%$ of theacreage, while 'C amarosa' isplanted on $35 \%$ 'Selva' is still planted on $9 \%$ of the acreage due to its extremely early production and ' $O$ so $\mathrm{Grande}$ ' is still planted on $\approx 5 \%$ of the state's acreage. The remaining $15 \%$ of the state's acreage is planted in proprietary and other cultivars.

Recent releases from the UCD program, including 'G aviota', may have an impact in Florida. 'G aviota' reportedly has more flavor and fewer disease problems than 'C amarosa'; however, it may not fruit early enough for Florida market needs. In addition, several advanced selections from the $U$ niversity of Florida breeding program show considerable promise for the future with good fruit quality and high earlyseason yields.

The southeastern region is also home to the third largest fresh market strawberry producer in the U nited States, N orth Carolina. The state mirrors the remainder of the region in several respects. First, strawberries are often produced asone component of a diversified small fruit and vegetable operation. Secondly, most of the strawberries in the region are produced on smaller farms ranging in size from 0.4 to 16 ha ( 1 to 40 acres) in size. M ost of thefruit issold as $\mathrm{U}$-pick or prepicked and marketed on-farm. Generally, wholesale marketing is a small proportion of sales for the region; however, so me growers are actively developing niche wholesale markets with local chain stores and attaining premium prices for fruit labeled as ripe, locally grown.

$\mathrm{H}$ igh temperatures and high humidity render 'C handler' susceptible to epidemicepisodes of fruit and crown rotting anthracnose outbreaks. In response, growersareexperimenting with 'C amarosa' and 'Sweet Charlie', neither of which yields as well as ' $\mathrm{C}$ handler'. In addition, the early flowering 'Sweet Charlie' can suffer frost/ freeze damage and subsequent yield reduction due to fluctuating late winter/ early spring temperatures. Several breeding programsincluding the N orth C arolina State U niversity and U SD A Beltsville, M d., programsare currently directing substantial effort at developing more regionally adapted strawberries that are resistant to fruit and crown rotting forms of anthracnose and that perform well in the annual production system.

StrawberRy cultivars for the MID-SOUTHERN UNITED STATESARKANSAS, KENTUCKY, MISSOURI, AND TENNESSEE. I n the mid-southern U.S., strawberries are often produced on relatively small farms as one component of a diversified farming operation. $\mathrm{N}$ early all the strawberry crop in the region is marketed on-farm as $\mathrm{U}$ pick or prepicked on-farm sales with a marked shift towards prepicked sales. Somegrowersin theregion arebranching out and selling prepicked strawberries in various retail outlets off the farm such asfarmers marketsand roadside stands.

Currently, Arkansas grows more than half of itscrop in the plasticulture system while Tennessee produces nearly one-fourth of itscrop on plastic. Relatively little acreage in Missouri and Kentucky is currently grown in the annual plasticulture system (T able 1 ). M ost all the acreage planted into the plasticulture system iscurrently planted with 'Chandler'. Growers in the region are experimenting with 'Sweet Charlie' and 'C amarosa' and are interested in finding more cold-adapted cultivars that will perform well in the plasticulture system.
Growers in the region have been quite conservative in regard to trying new cultivars in the matted-row production system. It has been said that $M$ issouri growers embrace an element of their state motto, the Show Me State, when it comes to using new cultivars. Thesentiment probably holds true for the region. From the mid1980 s to the early 1990 s, the primary early-season cultivars were E arliglow, Pocahontas, and Sunrise (Table 2). 'Earliglow' continues to be the primarycultivar for theearly season. There is little impetus for changing from 'Earliglow', although growers consistently mention they would likea larger fruited, heavier yielding 'Earliglow'type cultivar in the future. In cultivar trials conducted by Southwest M isso uri State U niversity researchers, the early-season cultivar C hambly has produced high yields of good quality berries and shows some promise for the region's growers.

For themidseason, growers in the region depended on 'Allstar', 'C ardinal', 'Guardian', 'H oneoye', 'Redchief', and 'Surecrop' in the recent past ( $T$ able 2 ). Currently, the picture looks much the same with the exception that 'Guardian' and 'Surecrop' are rarely used while 'J ewel' has become one of the top cultivars for this season. There are no new midseason cultivars that promise to make an impact in the region in the near future.

The mid-southern region has never had a strong late strawberry season. $\mathrm{H}$ igh temperaturesthat prevail by thistimedampen customer and grower interest in picking the crop. Growers in Arkansas found that once the ' $\mathrm{C}$ ardinal' crop was in, the strawberry season waslargely over. I $n$ a similar sense, Kentucky growers generally consider 'Allstar' and 'J ewel' to be their lateseason crop although some ' $L$ ateglow' is grown in the state. From the mid1980 s to the present, the primary lateseason cultivars used in the region have been 'ArKing' and 'Lateglow' (Table 2). N o newer late-season cultivars appear to be capturing any market hold in the region.

Future cultivars destined for either production system will need to have high quality and postharvest longevity to suit the region's direct-marketing scheme. Resistanceto common root and fruit rots will be important, especially in light of the probable loss of methyl bromide. There is consider- 
able interest in finding more adapted plasticulture cultivars for the region, particularly some with good cold hardiness. The industry is interested in types that produce an upright, thrifty canopy with reduced runnering that allowsgood air penetration, easier picking and increased fruit size. The growers in the region are also interested in plasticulture-adapted cultivars with increased resistance to root diseases such as red stele, fruit and crown rots such as anthracnose, gray mold caused by Botrytis cinerara Pers.:Fr. and leather rot caused by Phytophthora cactorum (Lebert \& Cohn) J. Schrt. These resistances will be particularly important as many of theregion'sgrowers feel they need to carry a plasticulture planting over for one or two additional years to make the up-front investment in planting economical.

StrawberRy cultivars fOR the MIDWESTERN UNITED STATES-ILLINOIS, INDIANA, OHIO, AND PENNSYLVANIA. The midwestern states producetheir strawberry crop almost exclusively in the traditional matted-row production system. H owever, in Illinoisthere are $\approx 30$ ha (75 acres) of strawberries planted into the annual plasticulture system (Table 1). Like many other regions in the eastern U .S., the M idwest has seen a fairly dramatic shift from predominantly $U$-pick marketing in the late 1970 s and 1980 s to prepick direct marketing. In Illinois, Indiana, and Pennsylvania, therehasbeen an overall decrease in strawberry acreage from the mid-1980s, although the decrease is not so dramatic as that witnessed from the 1960s into the 1980s. Generally, the acreage has stabilized within the last 5 years with the current trend being for fewer small acreage operationsand morelarger-scaleoperations. In O hio, strawberry acreage has remained fairly constant at $\approx 520 \mathrm{ha}$ ( 1300 acres) since 1968 (Scheerens and Brenneman, 1990)(T able 1).

Similar to the situation in the upper southern U .S., thecultivar picturein the M idwest islargely the sametoday as it was in the mid-1980s (T able 2). The standard early-season cultivars were Earliglow and $\mathrm{H}$ oneoye and that is still the case today. $\mathrm{H}$ owever, as in most of the east, acreage of ' $\mathrm{H}$ oneoye' has increased while 'E arliglow' acreage has decreased. The early season cultivar N ortheaster, released in 1994 (Galletta et al., 1995a), is considered to be a promising cultivar for the region.
The midseason cultivar story is a bit more complex due to interstate variation. 'Redchief' was one of the primary midseason cultivars in each state in the region in the recent past; however, from that point each state seemed to have its own particular suite of cultivars. Currently, 'Allstar' is the primary midseason cultivar in all states with 'Kent' popular in Pennsylvania, Illinois, and $\mathrm{O}$ hio. N otably, growers in the region feel that even though 'Allstar's' yields are lower than some newer cultivars, few if any cultivarscan match its percent marketability.

The loss of 'Blomidon' to J une yellows left the $M$ idwest searching for a late-season cultivar. Along with 'Blomidon', the M idwest used 'G uardian', 'J ewel', 'Scott', and 'Sparkle' to varying degrees in the late season, although there was no consensus regarding late-season cultivars(Table2). Currently, 'J ewel' and 'Lateglow' are the primary late-season cultivars in the region. As is often the case in the $M$ idwest, growers who can avoid or manage red stele choose the higher yielding red stele susceptible cultivar 'Jewel'. Alternatively, growers who have a red stele problem choose the resistant cultivar ' $L$ ateglow'. At present, there is no new late-season release that has been seen enough by growers to gain any widespread favor. G rowers in the northern parts of these states are quite interested in 'Winona', a 1996 U SD A-U niversity of $M$ innesotajointly released late-season cultivar adapted to the upper M idwest.

In the future, M idwest growers would like to see a high-quality lateseason cultivar that could fill the void left by the loss of 'Blomidon'. Because the primary market in the region is onfarm sales for fresh market, any cultivars used in the region will need to be comparable to, if not better than, existing cultivars such as 'E arliglow' and 'Allstar'. Traditionally, the strength of the eastern strawberry industry has been the excellent flavor of it's cultivars. $\mathrm{H}$ owever, because consumers are becoming accustomed to a Californiatype fruit, future cultivars will need to be larger-fruited and have good shelf life. Finally, because the strawberry crop is and probably will continue to be produced in the matted-row production system in the midwest, ( $\mathrm{H}$ ancock et al., 1997), disease resistance will continue to be of great importance in new cultivars.
StrawberRy CULtivars FOR the UPPER-MIDWESTERN UNITED STATES-IOWA, MICHIGAN, MINNESOTA, AND WISCONSIN. The four states considered as the upper-midwestern U nited States in this report roughly correspond with the northern province delineated by L uby (1989) in his report on strawberry cultivars for the $\mathrm{M}$ idwest and Plain states. Theregion experiences extreme winter cold and a protracted winter season. These winter conditions make cold hardiness and cold/ frost protection major considerations for the region's growers. Due to the length and severity of the winter season, growershave relied, and will in all likelihood continue to rely, on the matted-row production system ( $\mathrm{H}$ ancock et al., 1997). In the 1996-97 growing season it was estimated that there were only 4 ha (10 acres) of strawberries planted into the annual plasticulture system in the entire region (Table 1 ).

$\mathrm{N}$ early the entire crop in the region is direct-marketed. I n contrast to most of the eastern $U$ nited States, the upper midwestern growers still market the majority of their crop through U pick. H owever, prepicked on-farm marketing and sales in local farm markets are becoming more popular. In $M$ ichigan, the amount of the strawberry crop that is processed has been steadily dropping such that only $\approx 10 \%$ of the crop is processed in contrast to the $30 \%$ that was processed 20 years ago.

In his 1989 review, Luby stated that a number of new strawberry cultivars had been introduced in the previous decade and that most new plantingswereincluding some of these. The current cultivar situation is somewhat different in that most of the changes in cultivar usage in the region involve shifts to cultivars that were released in the 1979-89 period. From the mid1980 s to early 1990s the predominant early-season cultivars for the region were 'Earliglow', 'H oneoye', and 'V eestar' (T able 2). The current cultivar situation is the same except for a strong shift to 'Annapolis', particularly in the more northern parts of the region. 'Earliglow' and 'H oneoye' are more widely used in the so uthern portions of the region with 'H oneoye' acreage increasing at the expense of 'E arliglow' (T able 2). For the future, two newer releases seem to be attracting a lot of attention from the region's growers. In a M ichigan cultivar trial, 
'C hambly', a 1990 release from M cGill U niversity and Agriculture Canada, Q uebec, (K hanizadeh etal., 1990), produced high-quality medium-sized fruit and yielded second only to ' $\mathrm{H}$ oneoye' among early-season types ( $\mathrm{H}$ anson, 1997). 'N ortheaster' is also gaining favor in the region and is being more widely planted in I owa.

In the midseason, 'Allstar', 'Kent', 'Redchief', and 'Redcoat' had been the primary cultivars in the region. Currently, 'Glooscap' and 'Cavendish', releases from the Kentville, N ova Scotia breeding program have replaced 'Redchief' and 'Redcoat' and in combination with another N ova Scotia release, 'Kent', now dominatethemidseason acreage in the region ( $T$ able 2). For the future, two new releases are gaining much attention from growers in the region. 'M ira', a 1996 release from the Kentville breeding program, is a midseason cultivar that iscomparableto 'Kent' in many characteristicsincluding yield, fruit size, and taste. I $n$ addition, it is resistant to most common foliar diseases and the common races of red stele. 'M esabi', released in 1998, isthesecond cultivar from the joint U SD A-U niversity of $M$ innesota breeding program following 'Winona'. The program was designed to develop matted-row type cultivars adapted to the upper $M$ idwest that provided growers with increased resistancesto root rot diseases, primarily red stele. Both ' $M$ ira' and ' $M$ esabi' have produced good yields of largefancy fruit in various yield trials in the region.

Late-season cultivars that dominated the region from the mid-1980sto the early 1990s were 'Blomidon', 'Bounty', and 'Sparkle' (Table 2). As has been mentioned previously, 'Blomidon', another Kentville release, (1985), was quickly gaining favor throughout eastern $\mathrm{N}$ orth America. The loss of the cultivar created a gap that still exists. Presently, ' Jewel' and 'Lateglow' are being used in the late season in addition to 'Bounty' and 'Sparkle' (T able 2). H owever, some growers report that neither cultivar fruits significantly later than other late midseason cultivars such as 'Allstar'. T wo recently released lateseason cultivars have performed well in regional yield trialsand appear poised to makea market impact. 'L atestar', a1995 release from the U SD A breeding program in Beltsville (G allettaet al., 1996), wasthe highest yielding late-season cultivar in a M ichigan trial, and second in fruit size to its 'Allstar' parent ( $\mathrm{H}$ anson,
1997). 'L atestar' hasalso produced well in Wisconsin trials. 'Winona' also shows promise in the region and is resistant to the common leaf diseases and to the common races of red stele root rot. In $M$ innesota trials it hasyielded at least as well as any of the other late-season cultivars used in the region.

Growers in the upper midwest will continue to be interested in disease resistant cultivarsdueto the fact that the traditional matted-row production system used bytheregion'sgrowersgenerally carry over for 2 to 7 years, with an occasional 12-year planting not unheard of. Winter hardiness will always be an important trait for any new cultivars for thearea, as will be the ability to produce ample runners for bed formation. Because so much of the crop is directmarketed on-farm, future cultivars will need to be of high quality with good flavor, firmness, color, and shelf life. Growers are interested in seeing largersized fruit that compare more favorably with theC aliforniafruit consumershave grown accustomed to seeing on grocery shelves.

M orethan anywhere in the eastern U.S., growers in the upper midwest region have used and continue to show interest in day-neutral or everbearing type strawberries. L ess extreme heat in the summer growing months in the north leads to more flower bud initiation, allowing theseday-neutral typesto morefreelyexpresstheeverbearing character. Growers in the region are interested in the possibility of producing a strawberry crop on an annual basis, thereby avoiding the problems of bringing a crop through harsh winter conditions. It is fair to say that expectations have outstripped progress in the development of new day-neutral cultivars. L uby (1989) lists eight day-neutral cultivars that were trialed in M innesota in the late 1980s and significantly, no new cultivars have been added to this list in subsequent years. The 1981 U SD A releases 'T ribute' and 'T ristar' are still the most widely planted day-neutrals in the region. G rowersthroughout the region would welcomealarger-fruited, higheryielding replacement for the currently available day-neutral cultivars.

StrawberRy cultivars for the EASTERN CANADIAN PROVINCES-ATLANTIC PROVNCES, ONTARIO, AND QUEBEC. M ore than 5,900 ha $(14,750$ acres) of strawberries were planted in the eastern $\mathrm{Ca}$ nadian provincesin the 1996-97 season (Table 1). Roughly one-fourth to one- third of the crop is marketed as U -pick, with $\approx 70 \%$ being prepicked for on-farm or wholesale fresh market sales. Less than $10 \%$ of the crop isused for processing.

D ue to harsh winter conditions, a very small percentage of the strawberry acreage in the region is produced in the annual plasticulture system (Table 1 ). Current estimates suggest there may be up to 20 ha (50 acres) of J une-bearing strawberries planted in the annual plasticulturesystem currently in production in 0 ntario. The remainder of the strawberries planted on black plastic mulch in eastern Canada are day-neutral types, primarily 'Seascape', planted in Q uebec.

D espite the vast area encompassed by this regional treatment, the cultivar situation in eastern $C$ anada is fairly uniform, a situation attributed to thebroad adaptability of the cultivars grown in eastern Canada (D ale, 1989). In the recent past, 'Veestar' was the primary early-season cultivar in the region, but presently 'Annapolis' has overtaken 'Veestar' as the most popular earlyseason cultivar (Table 2). There is no consensus concerning an early-season cultivar for the future, although the 1994 release'M ohawk' isattracting considerable attention (Galletta et al., 1995b).

From the mid-1980s to the early 1990s, the principal midseason cultivar was 'Redcoat' (Table 2). H owever, 'Kent' displaced 'Redcoat' in this period ( $D$ ale, 1989). M ore recently, 'Glooscap' and 'H oneoye' have also been rapidly gaining in popularity and acreage. Currently, 'Kent' and 'H oneoye' are the primary midseason cultivarswith 'C avendish' being planted despite its tendency for uneven ripening. D ue to its excellent shipping characteristics, 'J ewel' is being planted also. The primary new midseason cultivar growersareconsidering is'M ira' (1996), which is productive and has good fruit shape and size, and shipping characteristics.

In the past, the primary late-season cultivarsfor theregion were'Blomidon', 'Bounty', 'M icmac', 'Sparkle', and 'Vantage' (Table 2). H owever, due to the large seasonal gradation between the southern and northern most extremes of these provinces, there has not been a large need for late-season cultivars in eastern Canada. G enerally, by the time the southern growers are finishing up with their midseason cultivars, thenorth- 


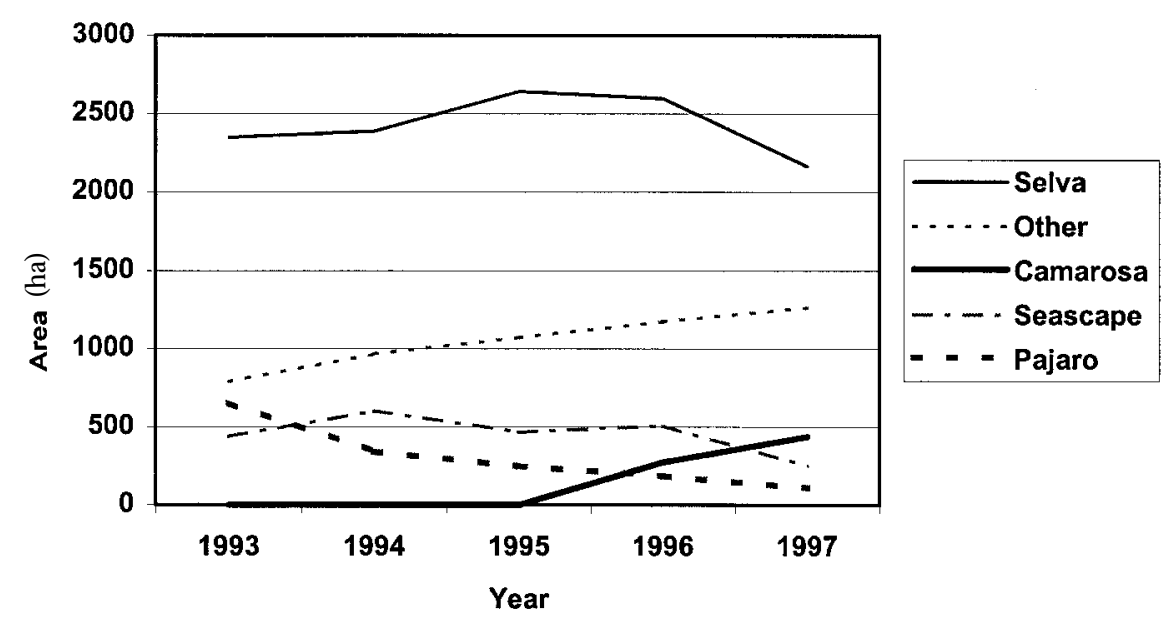

Fig. 1. (above) Acres of the major strawberry cultivars planted in northern C alifornia from 1993-97 (C alifornia Strawberry C ommission, 1997); 1 ha = 2.47 acres. (below) Acres of the major strawberry cultivars planted in southern C alifornia from 1993-97 (C alifornia Strawberry C ommission, 1997).

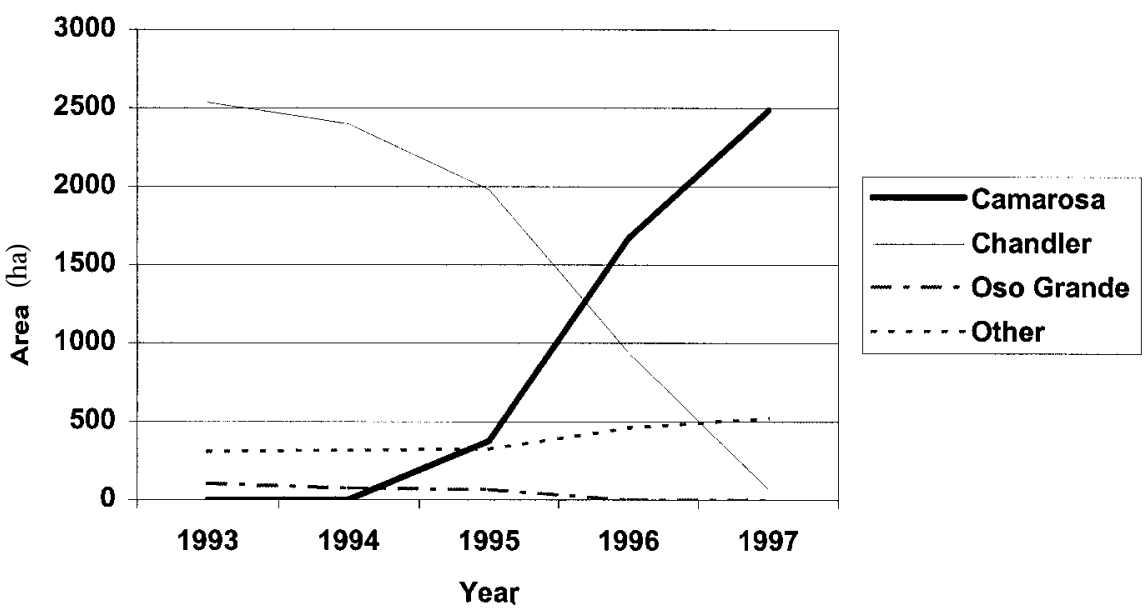

ern growers are just beginning to harvest their midseason cultivars. As a result, the acreage devoted to these lateseason types is not extensive. The lateseason cultivars that are used are generally older cultivars such as 'Bounty', 'M icmac', and 'Sparkle' (Table 2). Two releases from the $\mathrm{H}$ orticultural $\mathrm{Crops}$ Research I nstitute of O ntario, 'G overnor Simcoe' (1985) and 'Startyme' (1995) are being planted to a small degree in 0 ntario as late-season cultivars.

\section{Strawberry production and cultivars in the western United States}

Strawberry production in the western U .S. is dominated by $C$ alifornia and the Pacific N orthwest (PNW) harvest labor, and, especially in southern California, urban encroachment, the industry continues to be very strong. Concerted cooperation among industry commissions, growers, researchers, and packers suggests that these major problems will be overcome.

U nlike the eastern U .S. and C alifornia, much of the industry in the PNW is devoted to producing highquality strawberries for the processing industry. Although the region is the second most important in North Americafor the production of processing fruit, it produces the world's highest quality processing strawberries. While there is substantial production for the local fresh marketsin the Puget Sound area near Seattle-Tacoma, Wash., the Fraser River Valley near Vancouver, B.C. and Willamette Valley near Portland, Ore., a very high percentage of the acreage in the region is devoted to producing solely for processing. N ew cultivars developed for processing must cap (removal of calyx in the field as the fruit are picked) easily, have intense flavor, deep red exterior and interior color, maintain integrity after being processed (low drip-loss), and havehigh acid and sugar levels. In contrast to the cultivar situation for the fresh market, the processing industry relieson a very small number of cultivars that maintain market share for long periods of time, which renders the region's strawberry cultivar situation somewhat static.

While California continues to increase its production, the PN W industry is trying to find their place in the world strawberry market. The PN W cannot profitably sell fruit at the low prices that are common in California. In 1996 the price paid for processing strawberries in California was as low as $\$ 0.37$ to $0.44 / \mathrm{kg}$ (\$0.17 to $0.20 / \mathrm{lb})$ whilethenorthwest pricewasat $\$ 0.92$ / $\mathrm{kg}(\$ 0.42 / \mathrm{lb})$. In the PN W, \$0.92/ $\mathrm{kg}$ is not generally considered high enough a price to break even. In addition, the J une-bearing cultivars grown in the PNW only average yields of 16,000 to $23,000 \mathrm{~kg} \cdot \mathrm{ha}^{-1}((14,080$ to $20,240 \mathrm{lb} /$ acre), much less than the $110,000 \mathrm{~kg} \cdot \mathrm{ha}^{-1}(96,800 \mathrm{lb} / \mathrm{acre})$ that C alifornia growers are capable of producing with California-adapted cultivars.

East of the Cascade and Sierra $\mathrm{N}$ evada mountain ranges, the strawberry production picture changes dra- 


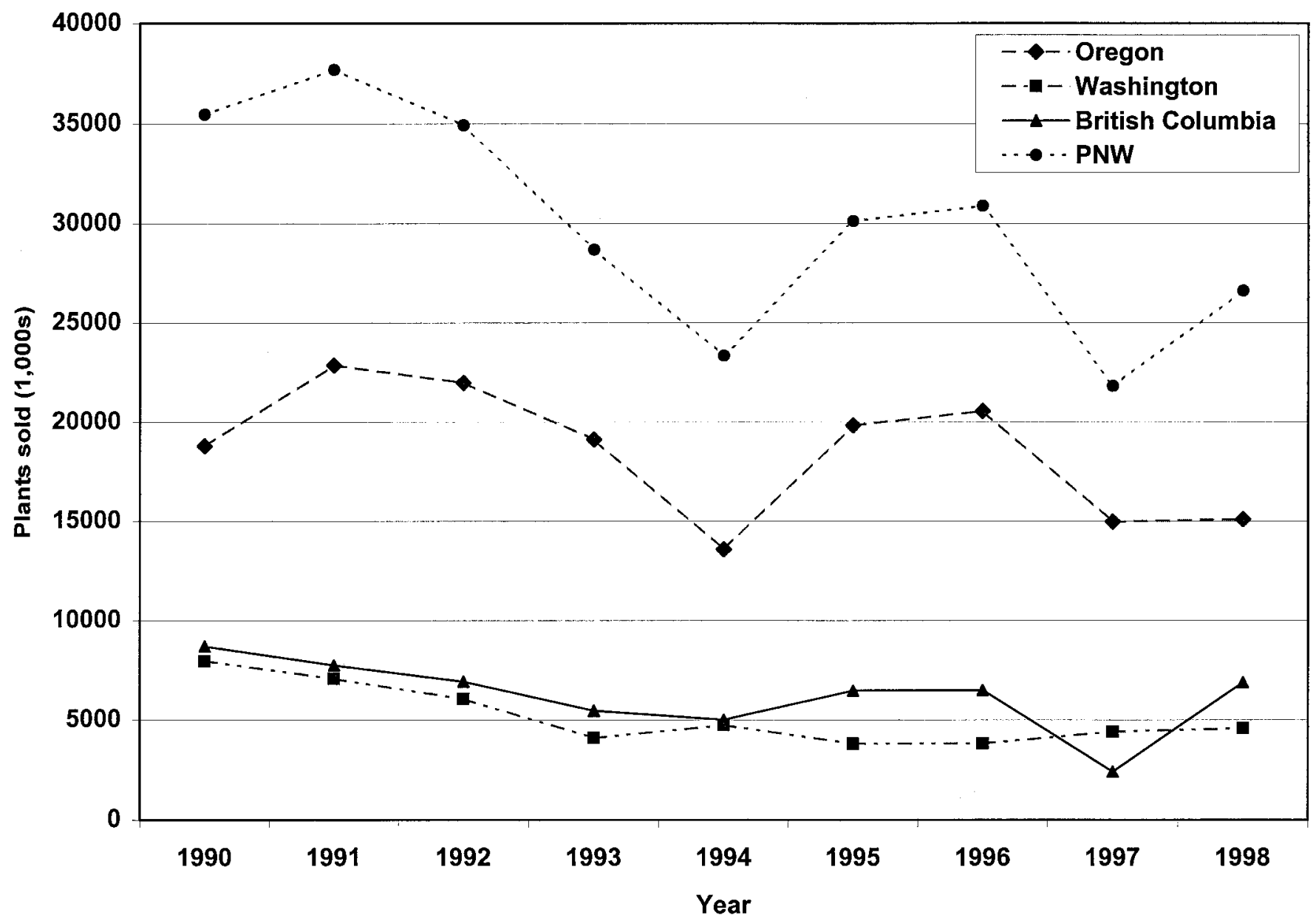

Fig. 2. T otal number of strawberry plants sold in B ritish C olumbia, Washington, O regon, and overall in the Pacific Northwest (P. Moore, personal communication); 1 ha $=2.47$ acres.

matically and begins to more closely resemble traditional eastern U.S. production. In these regions, a wide variety of cultivars are grown in small acreages for pick-your-own or local market sales. These areas tend to be planted with older cultivars that have proven reliablein specific regions. D ue to the small acreages and the fact that strawberries are usually produced as part of a diversified farming operation, there are very poor statistics available on the acreage in production in these western states and the mix of cultivars that are grown.

CaLIFornia. In California, nearly all of the strawberries are produced in an annual production system on fumigated soil on raised beds, mulched with plastic. The California industry is properly viewed as two major regions. Production in the southern California region (e.g., O range County near Los Angeles) isdo minated byJ une-bearing (short-day) cultivars that ripen fruit from early J anuary until A pril or $M$ ay. Production of day-neutral types in the northern California region (e.g.,
Watsonville and surrounding areas) begins in April, and continues until $\mathrm{O}$ ctober or $\mathrm{N}$ ovember. As northern Californiacomesinto production with a crop of primary fruit, the southern California fruit crop begins to be diverted to processing. Thus, most of the $C$ alifornia processing crop comes from southern California.

Southern California. The acreage planted to different cultivars in southern California has shown a remarkably quick and dramatic shift from 1995-97 (Fig. 1a). Whereas 'C handler' had dominated this market during the first half of the 1990s, it had all but disappeared by 1997 . While'C handler' was excellent for the fresh market, its predominance could also be attributed to the fact that it had better internal color and flavor than many of the major California cultivars of the 1980s, making it much better for processing. 'Chandler' has also proven to be remarkably adaptable in terms of its cultural requirements, e.g., date of planting, fertilizer regimes, and temperature limitations.
The rapid success of 'C amarosa', while remarkable, was not completely surprising. Before the introduction of 'C amarosa', southern Californiawasnot a major supplier to the fresh market until the beginning of February. With the introduction of 'C amarosa', southern California became capable of producing a marketable crop in early J anuary. While 'C amarosa' hasexcellent firmness, size, shipping quality and earliness, it does not have 'C handler' $s$ ' fresh market eating quality or its processing quality. In 1996, the year just prior to 'Camarosa's' complete domination of the market, the environmental conditions were ideal for its production. In the last 2 years, environmental conditions have been less conducive to outstanding performance, prompting the recognition that 'Camarosa' is not the perfect cultivar. Subsequently, whilenot as obvious as in northern California, there has been a steady increase in the "O ther" category of cultivars in southern California, due in large part to the increased importance of proprietary cultivars. 
Northern California. The northern C alifornia industry, centered near W atsonvilleand Salinas, has been dominated by the day-neutral 'Selva' (Fig. 1b). 'Selva' reliably produces a large crop of mild-flavored, firm fruit that have excellent shipping characteristics. 'Pajaro' and 'Seascape', which had been important cultivars for this region, are slowly disappearing from plantings. Surprisingly, 'C amarosa', a short-day cultivar, has been planted on 440 ha $(1,100$ acres) in this region. The other major trend has been the increase in importance of proprietary cultivars. There are at least five active private breeding programs in California that have developed their own cultivarsand these are grown along with the U CD developed cultivars. While these proprietary cultivars account for signifi- cant acreage in northern and southern California, they are not available to noncontracted growers. Increasingly, European strawberry breeding companies are testing their selections in California in hopes of capitalizing on the lucrative plant sales market there.

The new series of cultivars released from the U CD program in 1998 are starting to be tested enough to see their potential. The latest estimates are that 'D iamante' (Shaw, 1996a) and 'Aromas' (Shaw, 1996b) may make a significant impact on 'Selva' and 'Seascape' acreage worldwide (D. Shaw, personal communication). 'Gaviota' (Shaw, 1996c) has garnered some interest as it has fresh market potential and has processing characteristicsmore similar to 'C handler'. 'G aviota' is also unique because, while it is a short-day type plant, it tendsto return to fruiting in northern California with a pattern that is not distinguishable from many day-neutral cultivars.

The California industry will continue to be the world leader in fruit production, development of new production systems, and new cultivars. $\mathrm{N}$ ew cultivars with increased yield, quality, and horticultural characteristics will continue to arise from the various California programs dueto the potential financial payoff if a new cultivar gains a significant market share, and the intense competition within the industry to have the best cultivar possible.

Pacific northwest. The PNW presents two somewhat different faces. In general, the predominant industry is for processing, centered in 0 regon

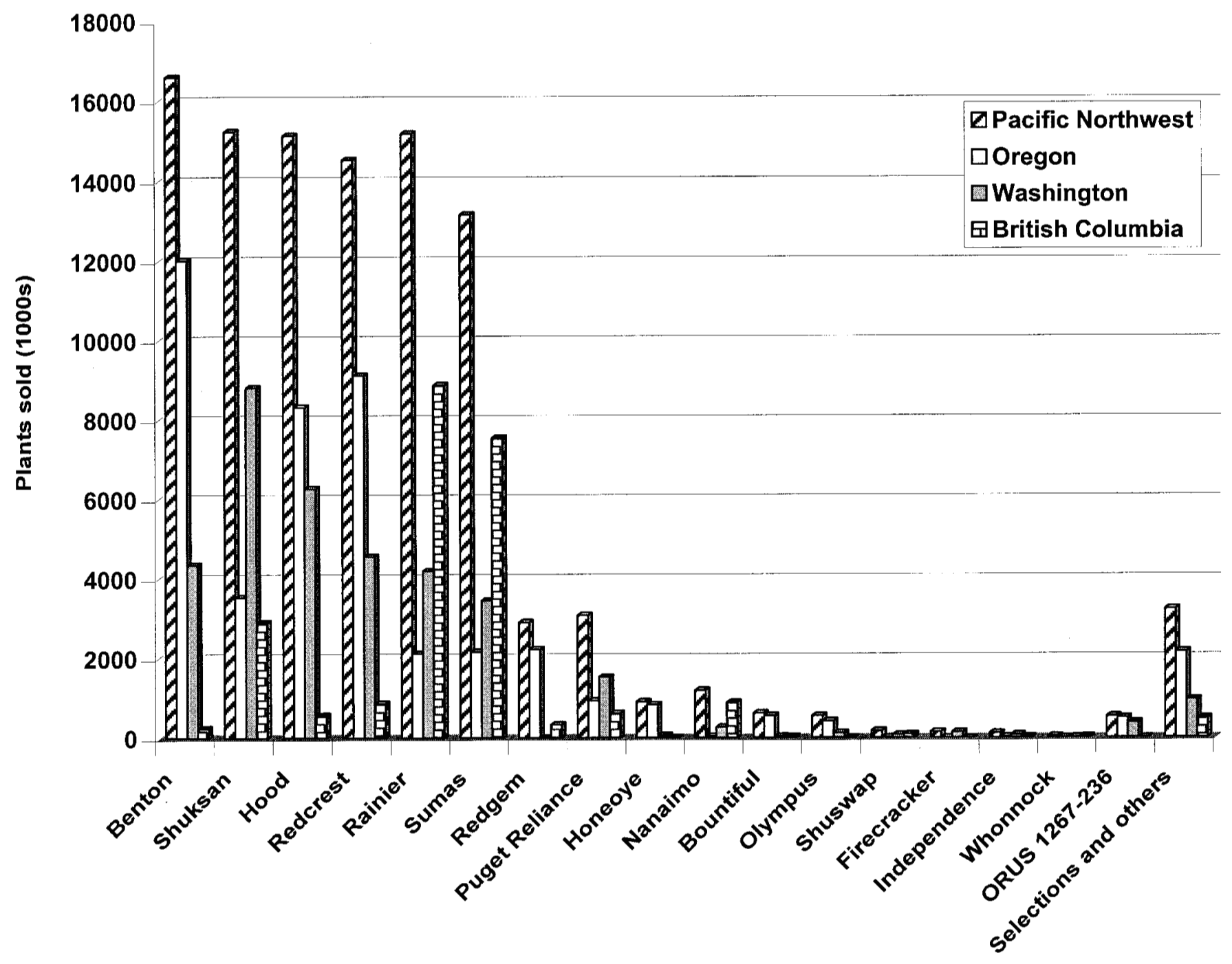

Cultivar

Fig. 3. Strawberry plant sales in British Columbia, Washington, Oregon, and overall in the Pacific Northwest for cultivars other than 'T otem' from 1990-97. 'T otem' is not included on this figure because it skews the graph so substantially that any other evaluations are difficult. (P. M oore, personal communication). 
and based on the cultivar 'T otem' (Fig. 2). Another much smaller component of the industry involves production for the fresh market on smaller farmsthat market on the farm (U - pick, prepicked) and in small, local wholesale markets. Whether fruit are produced for fresh or processed markets, the plants are grown in a matted row production system. The plantings are cropped for two and occasionally three fruiting seasons. Farms producing for the processing market average around 15 to 25 ha (37.5 to 62.5 acres) with some operations ranging up to 80 ha (200 acres). For fresh market and local sales, the farms are small with strawberry plantings ranging from 0.5 to 2 ha ( 1.25 to 5 acres) in size.

Processing market. In 1997, 'T Otem' accounted for $82 \%$ of the strawberry acreage planted in 0 regon. 0 ver the last 9 years, $74 \%$ of the acreage in $O$ regon and $62 \%$ of the entire PN W hasbeen planted in 'T otem' (P. M oore, personal communication). 'T otem' was released in 1971 and it is amazing that it is still so popular today ( $D$ aubeny et al., 1993). 'T otem' has maintained its popularity for several reasons. First, it is an outstanding genotype with excellent processing characteristics including intense flavor, high acidity, high sugar levels, solid red internal color, and the capacity to maintain integrity after processing. Second, 'Totem' is well adapted to the region with tolerance to most disease and virus pressures. Because 'T otem' has been grown in nearly a monoculture for 15 to 18 years, there are increasing concerns that it is now succumbing to a new resistance-breaking strain of the red stele root rot pathogen. Lastly, 'Totem' is popular due to the familiarity processors have with its processing characteristics; they know how it behaves in all their different product formulations. Adding new cultivars necessitates many adjustments to these formulations and the processing lines, therefore, it is very difficult to convince the processors to accept a new genotype.

Figure 3 depicts strawberry plant salesin the PN W bycultivar, excluding 'T otem'. Inclusion of 'Totem' in the figure obscured an illustration of many of the region's less significant cultivars. 'T otem' accounted for morethan 160 million plants sold over the last 9 years in the PN W; 121 million in Oregon, 33 million in British Columbia, and 12 million in Washington. ' $\mathrm{H}$ ood' and 'Redcrest' are currently the second and third most popular cultivars for processors in the region respectively (Fig. 3). Relatively similar numbersof thesecultivars have been sold in the PN W over the last 9 years with a high proportion of the ' $\mathrm{H}$ ood' plants being sold in Washington. While 'H ood' produces an excellent crop in Washington, the high percentage of this cultivar used in the state is influenced by contract sales to a few large processing operations. 'H ood' was released in 1964, before 'T otem', and its popularity hasfluctuated over theyears, although a blend of 'H ood' and 'T otem' for premium ice cream manufacturersisconsidered ideal. While'H ood' is outstanding for processed flavor and excellent for other processing characteristics, it isvirussusceptibleand without adequate vector [strawberry root aphid (A phis forbes Weeed), strawberry aphids ( $C$ hactosi phon fragaefolii Covkerell, C. jacobi H.R.L., C. minor Forbes, C. thomasi H .R.L.)]) control, the plants may succumb to virus soon after their first crop. 'R edcrest' is similar to 'H ood' in many ways. O verall, 'Redcrest', released in 1990, (Stahler et al., 1995) may be the most outstanding PN W cultivar for processed fruit quality and it can produce very high yields. U nfortunately, on some sites it can succumb to root rot, it is susceptible to virus pressure and powdery mildew [Spaerotheca macularis (Wallr.:Fr.) Jacz. f. sp. fragariae Peries], and ripens its fruit late. While lateripening hassomeadvantages, processors are often anxious to move on to the next fruit or vegetable in the season and do not like keeping their strawberry lines running late in the season.

A number of processing cultivars have had and continue to have a minor impact on the PNW industry. Most prominent among these are 'Redgem' and 'Bountiful'. 'Bountiful', released in 1993, fell into disfavor with the region's growers due to a relatively small average fruit size, particularly in the second year. M ore recently, growers in colder regions of B ritish C olumbia found 'Bountiful' suitable for their processing needs. 'Puget Reliance', released in 1994, (M oore et al., 1995) may yet prove to be an important cultivar. 'Puget Reliance' is similar to 'T otem' in most processing characteristics but has a lighter internal color and a higher drip loss. 'Puget Reliance' is virus tolerant, high yielding and produces large fruit. ' $N$ anaimo', another 1995 release ( $D$ aubeny and Kempler, 1997), was expected to be planted for the processed and fresh market; however, its size drops too quickly to justify picking costsfor processing.

Fresh market. As in the eastern U.S., the PNW fresh market strawberry industry is concentrated around population centers. A larger number of cultivars are included in the fresh market mix compared to the processing market, and big differences in cultivar popularity can be seen in the region (Fig. 3). 'Benton', originally released for the processing market in 1975, is now widely planted for the fresh market, primarily in Oregon. 'Benton', a late midseason cultivar, has excellent fresh flavor, medium-sized fruit, and an extremely vigorous plant even under viruspressure. 'Shuksan', a midseason cultivar, has been much more popular than 'Benton' for Washington growers, partly due to its cold hardiness. Released as a dual-purpose berry, 'Shuksan' has largely found its home as a reliable berry for roadside market and U-pick sales. 'Hood' is also grown for the early-season fresh market and has strong name recognition among consumers. F urther north, 'Rainier', and 'Sumas' have become popular, particularly in B ritish Columbia. 'Rainier', a sister seedling of 'Shuksan', was released in 1972. While it garnered some interest with the processors in the 1970s, it has primarily been used asan attractive, high-quality berry for local fresh market sales in the late midseason. 'Sumas' (D aubeny, 1987) is a reliable, early-season producer that is winter hardy, tolerant of virus, and resistant to red stele root rot. Some interest in 'H oneoye' as a very early-season berry developed in the late 1980s and early 1990s but difficulties in reliable cropping led to few new plantings.

Generally, cultivars developed in the PN W were selected for the processing market and thereforehavecharacteristics more suitable for processing. These processing typescan bevery desirable for a U -pick customer who intendsto immediately freezethefruit. The processing-type berries are difficult to sell retail for fresh use because they have a very short shelf-life. Some growers who are oriented towards the 
wholesale market are choosing California cultivars such as 'Selva'.

The trends of the last 20 years will continue in the western U .S. The California industry will continue to prosper with its ever-changing mix of cultivarsthat areideal for shipping around the world. The PN W will continue to dominatesome of theprocessing niches that have defined it for so me time with a gradually shifting complex of cultivars and a fresh market largely dependent on a mix of cultivars developed for processing. The regions between the western $G$ reat Plains and the $C$ ascades will continue to rely on a wide mix of cultivars for their diverse locations.

\section{Literature cited}

Bringhurst, R.S. and V. Voth. 1979. California strawberry cultivars-Past, present, and prospects. Fruit Var. J. 33:45-48.

Bringhurst, R.S. and V. Voth. 1989. California strawberry cultivars. Fruit Var. J. 43:12-19.

C aldwell, J.D . 1989. Southern U nited States strawberry cultivars. Fruit Var. J. 43:33-37.

Chandler, C.K. 1991. N orth American strawberry cultivars, p. 60-65. In A. D ale and J.J. Luby (eds.). Thestrawberry into the 21st century. Timber Press, Portland, O re.

Chandler, C.K., E.E. Albregts, and C.M. H oward. 1997. 'Sweet Charlie' strawberry. H ortScience 32:1132-1133.

D ale, A. 1989. Eastern Canada strawberry cultivars. Fruit Var. J. 43:38-41.

D aubeny, H .A. 1979. Thestrawberry cultivars of the Pacific N orthwest. Fruit Var. J. 33:44-45.

D aubeny, H .A. 1987. 'Sumas' strawberry. H ortScience 22:511-513.

D aubney, H .A. 1989. The changing strawberry cultivar situation in N orth America.
Fruit Var. J. 43:11.

Daubeny, H.A., F.J. Lawrence, and P.P. Moore. 1993. 'Totem' strawberry. Fruit Var. J. 47:182-184.

Daubeny, H.A. and C. Kempler. 1997. 'N anaimo' strawberry. H ortScience 32:1293-1294.

Galletta, G.J . 1979. Strawberry cultivars for eastern and midwestern North America. Fruit Var. J. 33:39-43.

Galletta, G.J. 1989. N ortheastern U nited States strawberry cultivars. Fruit Var. J. 33:31-33.

Galletta, G.J ., A.D. D raper, and H .J . Swartz. 1981. 'Allstar' strawberry. H ortScience 16:792-794.

Galletta, G.J., J.L. M aas, J.M. Enns, A.D. D raper, J.A. Fiola, J.C. Scheerens, and D.D. Archbold. 1995a. 'N ortheaster' strawberry. Adv. Strawberry Res. 14:73-78.

Galletta, G.J., J.L. M aas, J.M. Enns, A.D. D raper, A. D ale, and H.J. Swartz. 1995b. 'M ohawk' strawberry. H ortScience 30:631634

Galletta, G.J., J.L. M aas, J.M . Enns, J.C. Scheerens, R.J. Rouse, and R.F. H eflebower, J r. 1996. 'L atestar' strawberry. $\mathrm{H}$ ortScience 31:1238-1242.

Galletta, G.J. 1997. Strawberry, p. 669737. I n: R.M. Brooksand H .P. O Imo (eds.). The Brooks and O Imo register of fruit and nut varieties. 3rd ed. ASH S Press, Alexandria, Va.

H ancock, J.F., B.L. Goulart, J.J. Luby, and M.P. Pritts. 1997. The strawberry matted row: Practical cropping system or dated anachronism? Adv. Strawberry Res. 16:1-4.

$H$ anson, E. 1997. Strawberry varieties that have potential for Michigan. Great Lakes Fruit Growers N ews 12:36.

Jamieson, A.R. and K.A. Sanford. 1996. Field performance of June yellows-affected clones of 'Blomidon' strawberry. H ortScience 31:848-850.
K hanizadeh, S., D . Buszard, M . L areau, and D. Bagnara. 1990. 'Chambly' strawberry. H ortScience 25:984-985.

Luby, J.J. 1989. M idwest and plains states strawberry cultivars. Fruit Var. J. 43:22-31.

M aas, J.L., J.R. H arker, and G.J. Galletta. 1988. O ccurrence of an exotic race of Phytophthora fragariae in M aine. Adv. Strawberry Res. 7:42-44.

M aas, J.L., G.J. Galletta, and A.D. D raper. 1989. Resistance in strawberry to races of Phytophthora fragariae and to isolates of Verticillium from $\mathrm{N}$ orth America. ActaH ort. 265:521-526.

M oore, P.P., T.M . Sjulin, and C.H . Shanks, J r. 1995. 'Puget Reliance' strawberry. H ortScience 30:1468-1469.

O 'D ell, C.R. 1998. Strawberry research reveals a winner for colder areas. Amer. Fruit Grower 118:37.

O urecky, D.K. 1979. Strawberry cultivars of $\mathrm{N}$ ew York, $\mathrm{N}$ ew England, and Eastern Canada. Fruit Var. J. 33:38-39.

Poling, E.B. 1994. Strawberry plasticulture in N orth Carolina. Part II. Preplant, planting, and postplant considerationsfor growing 'Chandler' strawberry on black plastic mulch. J. Small Fruit Viticult. 2:53-79.

Scheerens J.C. and G.L. Brenneman. 1990. Survey of $\mathrm{O}$ hio strawberry growers: Present practice and future directions. Ohio Agr. Res. D ev. Cntr. Res. Circ. 297:39-49.

Shaw, D.V. 1996b. 'Aromas' Plant Patent 10451, 12 N ov.

Shaw, D .V . 1996a. 'D iamante' Plant Patent 10435, $12 \mathrm{~N} \mathrm{ov}$.

Shaw, D.V. 1996c. 'Gaviota' Plant Patent 10461, 12 N ov.

Smith, C.R. and D.H. Scott. 1969. Strawberry varieties in the U nited States- 1968. Fruit Var. H ort. Dig. 23:26-30.

Stahler, M.M., F.J . Lawrence, L.W. M artin, P.P. M oore, H .A. Daubeny, W.A. Sheets, and G.W. V arseveld. 1995. 'R edcrest' strawberry. $\mathrm{H}$ ortScience 30:635-636. 